\title{
Regenerative Orthopedics
}

\author{
Christopher J. Centeno and Stephen J. Faulkner \\ The Centeno-Schultz Clinic \\ United States of America
}

\section{Introduction}

Mesenchymal stem cells (MSCs) are multipotent, adult stem cells that show clinical potential as therapeutic agents in regenerative medicine(Bruder et al., 1994; Barry, 2003; Alhadlaq \& Mao, 2004; Gangji et al., 2005; Cha \& Falanga, 2007). They are also known as marrow stromal cells and are derived from mesodermal tissues. The clonal nature of a subpopulation of marrow nucleated cells was discovered in the 1960's (Becker et al., 1963). These cells were later assayed and renamed "colony forming fibroblasts" (Friedenstein et al., 1974). Experiments through the 1980's and 1990's demonstrated that environmental clues assisted MSCs in differentiating into different cell types. For example, culturing with ascorbic acid, inorganic phosphate, or dexamethasone could differentiate cells to osteoblasts, while culturing in the presence of TGF-beta caused cells to differentiate into chondrocytes (Alhadlaq \& Mao, 2004). More recently it has been shown that bone marrow MSCs are actually a heterogeneous population of similar cells rather than one distinct cell type (Zhou et al., 2005). As a result, there is still no uniformly accepted definition of an MSC. Despite this issue, some groups have attempted to provide a definition which consists of adherence to plastic, MSC specific cell surface markers consistent with MSCs, as well as multi-lineage mesodermal tissue differentiation (Schauwer et al., 2010).

\section{Cell source matters}

MSCs can be easily isolated from many anatomic locations, including whole marrow aspirate, marrow mobilized whole blood, muscle biopsy, adipose liposuction aspirate, and other tissues (Alhadlaq \& Mao, 2004). For orthopedic uses, these sources have been compared by many authors for their ability to heal bone and cartilage with differences being uncovered. As a rule, the closer the source tissue is to the target tissue being treated, the more effective the MSCs appear to be at differentiation to the target tissue type. For example, Vidal compared equine MSCs derived from bone marrow (bm-MSCs) vs. adipose tissue (a-MSCs) for chondrogenic potential and found that bm-MSCs produced a more hyaline like matrix and had improved glycosaminoglycan production (Vidal et al., 2008). Additional animal studies demonstrated that bm-MSCs produced better repair of a tibial osteochondral defect when compared to aMSCs (Niemeyer et al., 2010). Keeping with this trend, Yoshimura determined that MSCs derived from the synovial tissue of the knee (closest to the target tissue of chondral cartilage) had better chondrogenesis than bm-MSCs (Yoshimura et al., 2007).

Significant controversy exists over whether adipose or bone marrow are better sources for orthopedic tissue repair (Frisbie et al., 2009). While adipose MSCs are more prevalent and 
are capable of orthopedic tissue differentiation, obtaining orthopedic tissues from these type of cells requires the use of considerably more growth factors. In addition, as stated above, the native chondrogenic potential of adipose derived MSCs doesn't appear to be as robust as bone marrow derived MSCs.

\section{MSC culture expansion}

A limited amount of cells can be obtained from any tissue. In many instances, the number that can be harvested from the source tissue is less than the quantity of cells needed for tissue repair. One method of obtaining more cells is culturing to obtain larger numbers. However, a delicate balance exists between length of time in culture (which produces more cells) and adverse consequences to the cells (such as genetic transformation).

MSCs are usually culture expanded via monolayer culture, which is a process that involves seeding a certain density of cells onto a specialized flask and allowing the MSCs to attach to a plastic surface and begin to form colonies. In this way, MSCs are selected from the marrow nucleated cell population through adherence. The MSC's that are adherent are then fed via a nutrient broth that is maintained above the growing cells. Oftentimes flasks are used with multiple surfaces to enhance cell production versus available incubator space. Because MSCs are contact inhibited, they will grow on this surface until they become confluent and then abruptly stop propagating. It is commonly believed that this "contact inhibition" property of MSCs is a key feature of their enhanced safety profile over other stem cell types that will propagate indefinitely without exhibiting contact inhibition. To keep MSCs proliferating in culture, when the colonies are near confluence, the non-adherent cells in the media are discarded and an enzyme is used to detach the MSCs from the plastic surface. The MSCs are then re-plated in a similar flask and fresh media added with this process being known as a "passage". Most MSCs in culture are grown to the $2^{\text {nd }}$ to $5^{\text {th }}$ passage, as some studies have shown decreased differentiation if MSCs are grown for prolonged periods in culture with a higher chance of genetic mutation (see Fig. 1)(Banfi et al., 2000; Crisostomo et al., 2006; Izadpanah et al., 2008). Thus MSC culture is a balance between being able to grow additional cells for therapy without culturing for prolonged periods. Most studies consider that a "pure" MSC population is obtained after approximately the second passage.

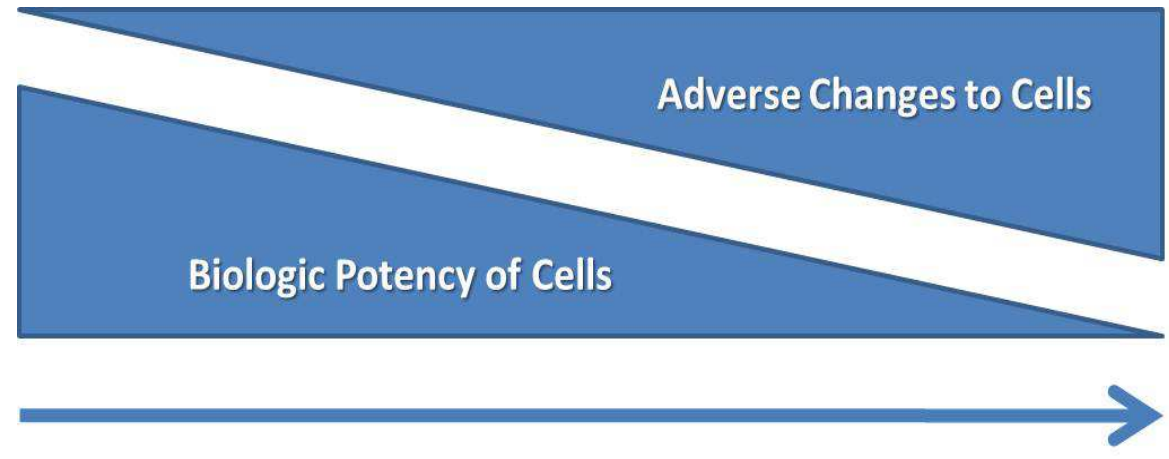

\section{Time}

Fig. 1. Adverse changes in cells increase with time in culture as biologic potency decreases. 


\section{How MSC's effect tissue repair}

Animal studies have demonstrated the multipotency of MSCs, and how they can differentiate into muscle, bone, cartilage, tendon, and various cells of internal organs. However, these cells also act via paracrine mechanisms to assist in tissue repair. For cell therapy, paracrine is defined as the production of certain growth factors and cytokines by the MSCs which can assist in tissue repair (Ladage et al., 2007). These growth factors include TGF-beta, VEGF, FGF, and other signaling factors that can help recruit other cells to the local area. In this way, MSCs can act as a coordinator of the repair response without having to act directly through differentiation to repair tissue. In fact, some have questioned whether most of the positive repair effects observed in experimental MSC therapies are due more to this paracrine signaling than differentiation of cells. In the end, it may not matter if MSCs act through differentiation or orchestrate the repair response, as long as the robustness of the repair meets the clinical need.

\section{Donor vs. autologous MSC sourcing}

Autologous stem cells obviously do not have the same communicable disease transmission risk as donor allogeneic cells. However, there may be practical reasons why donor cells are attractive. For example, some studies have shown a decreased differentiation potential for MSCs obtained from older patients (Zhou et al., 2008). In addition, somatic genetic variants (i.e. trisomy V and VII) have been demonstrated in the MSCs and osteoprogenitors of some patients with osteoarthritis (Broberg et al., 1998). In addition, allogeneic cells could be able to be mass produced in bioreactors, providing a ready supply of cells for therapy. On the other hand, some concerns have been raised about the use of allogeneic stem cells. As an example, Ueda recently discovered that stem cells transplanted from the bone marrow of elderly mice bred to have osteoporosis were able to induce osteoporosis in young healthy mice, indicating that the stem cells themselves may be a genetic disease vector (Ueda et al., 2007). In addition, many have argued that allogeneic MSCs are immune-privileged as they lack major histocompatibility complexes; however, Prigozhina has found that allogeneic MSCs lose their immunosuppressive potential in a mismatched setting (Prigozhina et al., 2008). In addition, Huang recently noted that MSCs transplanted for cardiac repair lost their immune-privileged status and transitioned to an immunogenic state after differentiation, limiting their usefulness in cardiac repair (Huang et al., 2010). In summary, while allogeneic MSCs may solve some issues such as cell availability on demand and mass distribution, they also present many hurdles that have to be overcome to allow lab to bedside translation.

\section{MSC use in orthopedic specific conditions}

\subsection{Fibrocartilage-meniscus repair}

The challenge in repairing the meniscus is due to the poor blood supply of the inner $2 / 3^{\prime} \mathrm{rds}$ (where many tears occur) versus the good blood supply of the outer 1/3 (red zone-where fewer non-healing tears are observed) (Hennerbichler et al., 2007). As a result of these differences in meniscus blood and nutrient supply, surgical repair of a meniscus tear is more likely to be successful in the outer $1 / 3$ than the inner $2 / 3$ rd's. To overcome this limited healing ability of the inner $1 / 3 \mathrm{rd}$ of the meniscus, many surgeons often perform a partial mensectomy for tears of this area, which can lead to significant biomechanical abnormalities 
in the knee (Sturnieks et al., 2010). The promise of stem cells if used to enhance surgery may thus be in allowing the surgeon to repair the inner meniscus. For example, Izuta et al demonstrated that cultured MSCs may be able to overcome this problem of poor repair in the avascular zone. His group was able to demonstrate meniscus repair in the white zone when MSCs were transplanted into this area using a fibrin matrix (Izuta et al., 2005). Of note, Agung et al (2006) reported a murine model of intra-articular injection after acute injury of multiple knee structures, including the meniscus. This model demonstrated that for blind intra-articular injection (rather than the local adherent model proposed by Koga), the number of cells injected was related to their ability to be found in the meniscus. For example, at a dose of $1 \times 10^{6} \mathrm{MSCs}$, none were found in the injured meniscus but at a dose of $1 \times 10^{7}$ cells, MSCs were generally found in this area. This may fit well with Koga's hypothesis that MSCs act primarily where they physically attach, as a higher number of cells injected into the joint would make it more likely that cells would be able to attach at the site in need of repair (Koga et al., 2008). Horie et al (2009) reported that synovial derived MSCs that were injected into massive rat meniscus tears were able to differentiate and repair meniscal tissue. Of note, the authors also demonstrated that these cells did not migrate out of the knee to distant organs, further enhancing their theoretical safety profile for clinical use. Finally, Yamasaki et al (2005) validated that MSCs were capable of repopulating the meniscus. This investigator cryogenically treated the meniscus to kill the living cells and then reseeded it with cultured MSCs. The resulting tissue had appropriate biomechanical properties approximating the normal meniscus.

\subsection{Hyaline cartilage: chondral defects}

Some of the earliest models of cartilage repair used autologous, cultured chondrocytes (Brittberg et al., 1994). However, the complications of using chondrocytes for cartilage repair included hypertrophy, graft failure, long culture times, and the invasiveness of the implant procedure (Nejadnik et al., 2010). Because MSC's are multi-potent and have shown to have innate cartilage repair properties through both differentiation and paracrine signaling, animal models of cartilage repair using MSCs started to appear in the literature in the early 1990's (Caplan, 1991). In these studies an osteochondral defect (OCD) was created experimentally and the MSCs were implanted into the lesion, often in a hydrogel or other carrier or at times through local adherence (Minas \& Nehrer, 1997; Buckwalter \& Mankin, 1998; Angele et al., 1999; Johnstone \& Yoo, 1999). Partial to robust healing of the OCD takes place over weeks to months (Alhadlaq \& Mao, 2004). The cartilage produced by these cells was very much like native hyaline cartilage, but subtle differences have been observed (Katakai et al., 2009).

\subsection{Biologic scaffolding}

MSCs can be delivered to the lesion area in many different biologic scaffolds including hydrogels, fibrin, in native extra-cellular matrix, collagen, or in a suspension. A scaffold is a matrix with properties that support cell migration, attachment, three dimensional position, and engraftment. Based on unpublished data, we have noted that stiffer biologic scaffolds (like dense fibrin glue) tend to reduce MSC viability as they limit MSC movement through the material. On the other end of the spectrum is implanting MSCs without scaffolding. In this method, cells are delivered in a liquid suspension and slowly dripped on the lesion, using gravity dependent adherence to allow site attachment. For 
example, Fig 2 shows histology adapted from Koga et al (2008) demonstrating minimal cartilage repair with a control saline injection, minimal repair with MSC's injected intra-articular, and robust repair when MSCs were allowed to attach to the lesion via gravity.

Based on the published data showing the importance of MSC attachment to a lesion, we would hypothesize that exact placement of MSCs in a joint is very important. For example, blind intra-articular injection of MSCs or the placement of cells into the intra-articular cavity after surgery is likely to be less effective for facilitating repair than placement of cells at or near a lesion in need of repair. This exact placement of cells has been already used in daily orthopedics practice, for example in the Autologous Chondrocyte Implantation procedure $(\mathrm{ACI})$ as well as in knee micro fracture. The knee ACI procedure depends on exact placement of cultured chondrocytes into an osteochondral defect through injection under a surgically prepared periosteal flap. The micro fracture procedure also relies on the surgeon creating holes in the osteochondral plate of an OCD (Osteochondral Defect) which allows whole marrow and a limited number of MSCs to clot in the defect.

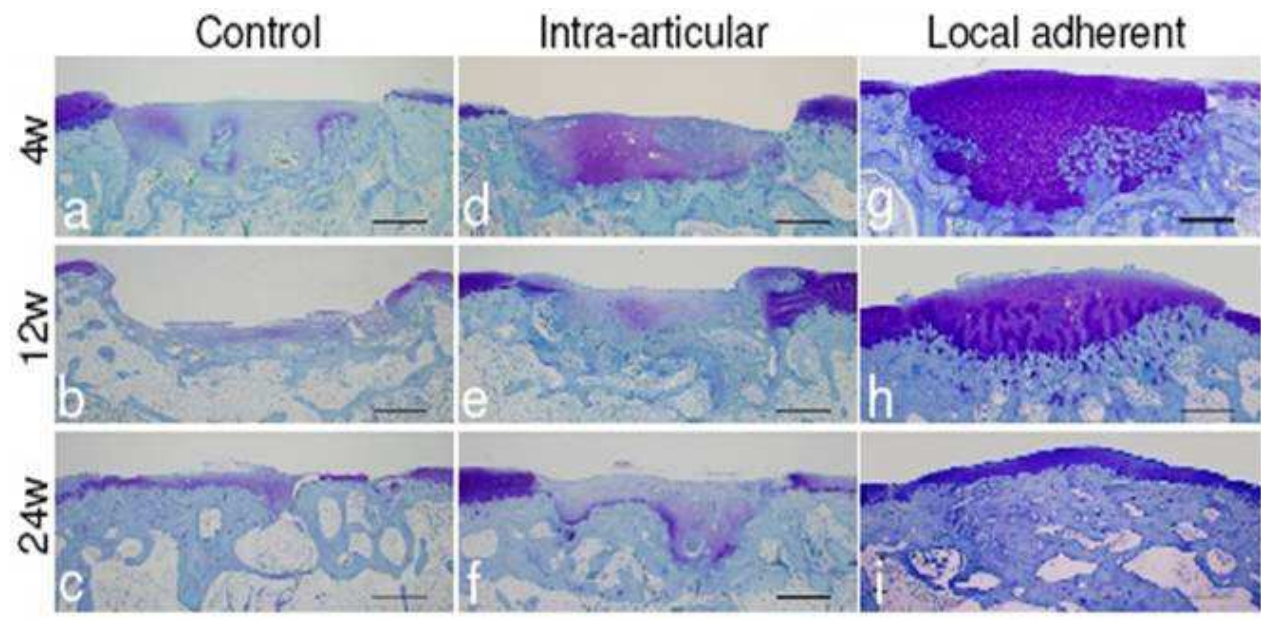

Fig. 2. Histology of chondral cartilage repair after staining, showing little repair in a control injection, some repair in a blind intra-articular injection of stem cells, and robust repair when cells were dripped on the lesion.

While existing cell based procedures for the knee have some reported success, both of these techniques seem to be more effective in younger, athletic patients. In addition, in both procedures, the cartilage produced by either chondrocytes or the low concentration of MSCs in a micro fracture clot tends more toward non-native fibrous cartilage versus the more hyaline like cartilage produced by higher concentrations of cultured MSCs (Mobasheri et al., 2009). Recently, Mcllwraith et al have improved upon the standard micro fracture concept in an equine model by adding $\mathrm{MSC}^{\prime} \mathrm{s}$ to the joint after surgery, demonstrating better cartilage repair with a combination of micro fracture plus MSCs than microfracture alone (McIlwraith, 2010). In this study, the repaired tissue was significantly firmer and had higher levels of aggrecan, a molecule that provides compressive stiffness to cartilage. 


\subsection{Tendon repair}

Tendon tears are often difficult to treat without a high level of morbidity or re-rupture. This may be because of the high tensile strength tendons are required to bear as well as the fact that sutures in the tendon itself may reduce local blood flow, further impeding the repair process. Awad has published a rabbit model demonstrating that cultured MSCs were able to assist healing and produced better tendon appearance than non-MSC treated tendons. The MSC treated tendons had better maximum stress, modulus, and strain energy density as well as minor improvements in the histological appearance, including an increased number of tenocytes and larger and more mature-looking collagen fiber bundles (Awad et al., 1999). The same author later published that the seeding density of MSCs in the biologic scaffold and control over the rate of contraction of the healing tendon were important for successful MSC mediated tendon repair (Awad et al., 2000). Chong also demonstrated improved modulus in resected rabbit Achilles tendons treated with MSCs and morphometric changes, concluding that MSCs can improve the histological and biomechanical parameters in the early stages of tendon-healing (Chong et al., 2007). On the other hand, Gulotta was unable to demonstrate efficacy for an animal model of surgical rotator cuff tendon healing which showed no differences between MSC treated and untreated groups (Gulotta et al., 2009).

\subsection{Intervertebral disc repair}

Traditional spinal surgery treatments for degenerated intervertebral discs continue to show disappointing results (Deyo et al., 1993; Elias et al., 2000; Fritzell et al., 2003). While animal models of disc repair using MSCs are abundant, human data isn't readily available. For example, Sakai et al $(2003,2006)$ have published several animal models whereby MSCs are usually combined with atellocollagen and inserted into an experimentally created degenerative disc. This group of authors has observed encouraging improvements in MRI disc hydration, height, and morphology. Richardson et al (2004) and Risbud et al (2004) have investigated the co-culturing of MSCs with cells from the nucleus pulposis (NP) showing that this technique can produce partially differentiated cells that are capable of repopulating the NP in an animal model. Risbud et al (2004) has also used different methods for MSC differentiation toward the NP phonotype including using MSC exposure to hypoxia and TGF-beta in culture. Zhang et al (2005) has shown that MSCs injected into discs without pre-conditioning or co-culture can help to increase proteoglycan production in the NP. Finally, Miyamota et al (2010) recently demonstrated that intra-discal transplantation of synovial derived MSCs prevented disc degeneration through suppression of catabolic genes and perhaps proteoglycan production. In summary, while the results from animal models are impressive, questions remain as to whether a quadruped disc with its very different load characteristics can serve as an adequate model for bipedal disc repair. In addition, in all of the animal models studied to date, an artificially created degenerated disc (acute disc stab model) is used as a surrogate for the chronic degenerated discs normally encountered in patients (Yoshikawa et al., 2010).

\section{Cell delivery in orthopedics}

Delivery of cells into a joint to treat orthopedic injuries could take two common routes used daily in clinical practice: percutaneous injections and arthroscopic placement. Injecting cells 
into a confined space such as infiltrating into soft-tissues will likely result in the MSC's that stay local to the injection site. However, as discussed above, injecting in a large joint presents some concerns, as multiple animal models have shown that cells may or may not find their way into the damaged areas(Agung et al., 2006). Because MSC's function through local attachment to the damaged site, MSCs dripped on a lesion surgically or through a needle are another possible implant route. Other injection based methods may involve using MSCs tagged with ferrous nanoparticles and magnetic fields to encourage attachment to the damaged site (Kobayashi et al., 2008). Finally, since MSCs are capable of chemotaxis, placing certain growth factors on the injured tissue may result in more MSCs accumulating at the lesion (Fiedler et al., 2002).

Another challenge in MSC delivery is that most arthroscopic surgery is performed in a water environment. For cells in suspension, this presents a challenge, as the MSCs would easily be whisked away by the action of arthroscopy pumps meant clear debris from the operative site. To overcome this problem, Nejadnik et al (2010) have used a surgical approach similar to autologous chondrocyte implantation, where MSCs are placed in a dense hydrogel and sutured under a protective membrane. While this technique has promise, it's also more surgically invasive with likely higher morbidity than injection. Another alternative method is to adapt the MSC properties to be better suited for the water arthroscopy environment. For example, MSCs can be cultured to form a tissue engineered construct (TEC) by allowing the cells to produce their own extracellular matrix. The result is a pea sized implant with a paste like consistency that can be placed under water arthroscopy into a lesion or defect (Ando et al., 2007).

\section{From the bench to the bedside in orthopedics}

The clinical translation of MSCs from the lab to the bedside is clearly imminent. For example, our use of MSCs in orthopedics began in 2005 and we have published case studies in which positive MRI changes in cartilage and meniscus were observed in knees treated with culture expanded MSCs and hips treated with nucleated cell concentrates, corresponding with symptomatic improvement (Centeno et al., 2006; Centeno et al., 2008; Centeno et al., 2008). We have also noted that the complication rate of expanded MSC injection procedures is no greater than other needle-based interventional techniques directed at peripheral joints (Centeno et al., 2010). In a submitted and recently accepted publication on 339 patients, this safety profile was continued at up to three years post MSC reimplantation with over 200 MRI's of the reimplant sites showing no evidence of ectopic tissue or tumor formation (see Fig 3). Other authors have described similar safety profiles using more invasive surgical implant techniques. Wakatani described effective treatment of cartilage defects in 9 knees with culture expanded MSCs (Wakitani et al., 2007). These authors also published an 11-year prospective study of 45 knees (in 41 patients) treated with autologous cultured, bone marrow MSCs, with results indicating both safety and efficacy (Wakitani et al., 2010). Nejadnik recently described a comparison between surgically implanted chondrocytes versus cultured MSCs placed by needle in 72 knees of older patients.(Nejadnik et al., 2010) The MSC treated knees demonstrated good safety, less donor site morbidity, and better efficacy when compared with an autologous chondrocyte implantation procedure. Finally, Haleem has noted that autologous, cultured bm-MSCs reimplanted into articular cartilage defects in platelet rich fibrin demonstrated evidence of healed cartilage in most patients at 12 months post-operative.(Haleem et al., 2010) 


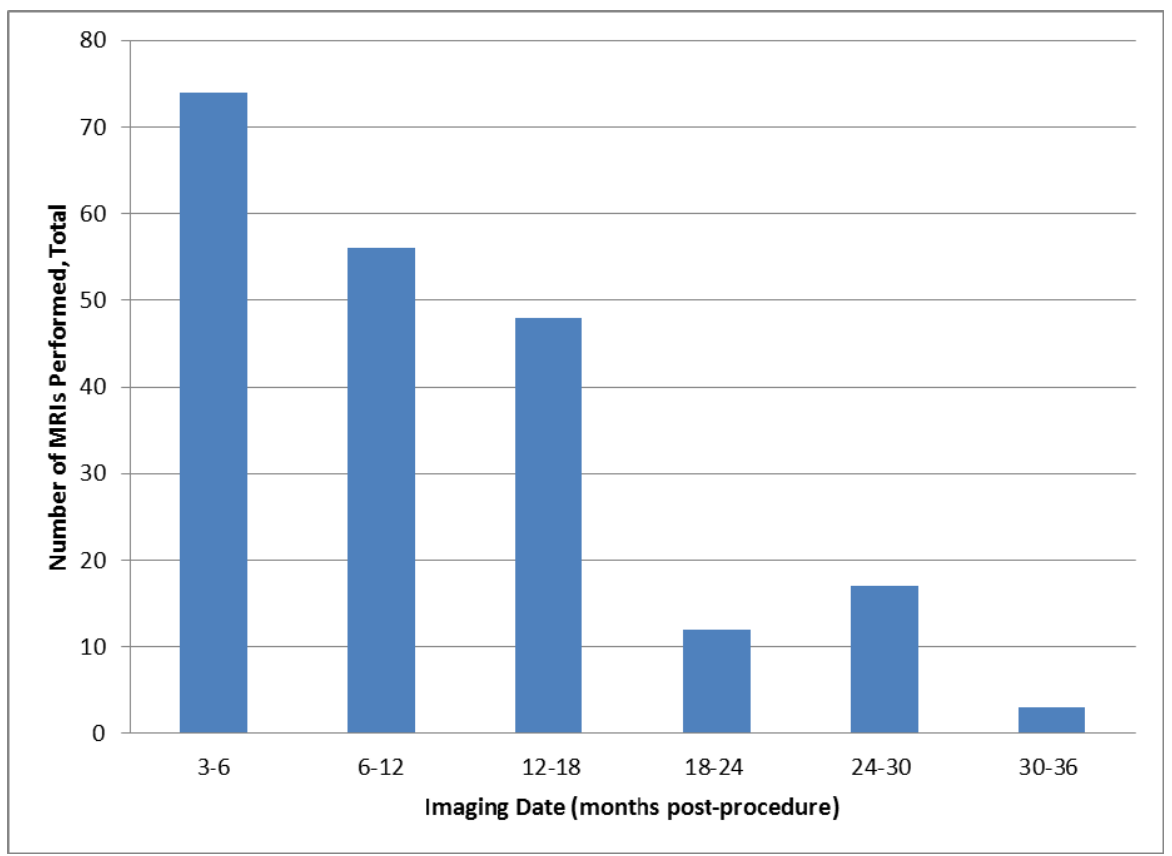

Fig. 3. Number of negative MRI follow-ups at re-implant sites for each end-point for 50 patients tracked after orthopedic MSC reimplantation.

While very little has been published on intervertebral disc repair in humans, some clinical data is available. Yoshikawa recently published on two patients who were treated with surgically implanted MSCs that were cultured using a serum free technique (Yoshikawa et al., 2010). After two years, no complications were noted and both patients showed modest improvements in vacuum phenomena on follow-up MRI. The only other human data of which we are aware is that produced by our group from 2005-2010 under IRB supervision and now being readied for publication (unpublished data). Our experience demonstrated that placing a bone marrow nucleated cell fraction (an enriched MSC population with other cells) into the disc via percutaneous means produced no measureable clinical or MRI results in patients with degenerative disc disease. Replicating the Sakai study (Sakai et al., 2003), where cultured MSCs were placed into the disc in a similar patient population also produced little measureable results. Finally, a third case series was performed where changes were made in culture and injection technique as well as the diagnosis being treated (changed from DDD to chronic disc bulge causing lumbar radiculopathy). This last model showed encouraging clinical and imaging results.

\section{Implications in real world clinical applications}

To consider the real world implications of viable cell based alternatives to more invasive orthopedic surgeries, total knee arthroplasty (TKA) is an apt model. Knee replacement surgery, also called knee arthroplasty, has been employed increasingly over the past 10 years as a means of treating symptomatic degenerative changes of the knee. It is estimated 
from discharge data from the Nationwide Inpatient Sample (NIS) of the Healthcare Cost and Utilization Project (HCUP), that the number of partial and total knee replacement procedures among U.S. patients 65 years and older increased dramatically from 178,653 in 2000 to 357,472 in 2008 (HCUP, 2008). Knee arthroplasty is associated with substantial mortality and morbidity; applying rates derived from 2000 data resulted in an estimated 4,964 TKA related deaths, 2,788 pulmonary emboli, 2,908 myocardial infarcts, and 4,670 cases of pneumonia (Mahomed NN, 2005). In contrast, we have recently submitted for publication a large case series of 202 knee and hip osteoarthritis patients treated with percutaneous injection of MSC's. As an example, while 2/3'rds of the knee patients were TKA candidates, only 6 knee patients reported TKA within an average total surveillance period of $>2$ years despite the injection. In addition, statistically significant differences in reported outcome between the treatment and an untreated control were observed. Finally, complications rates were minimal compared to TKA.

\section{Regulatory processes}

The regulatory environment in the United States and Europe for stem cells that are more than minimally manipulated considers these cells in the same regulatory category as mass produced drugs. This "drug" category includes cultured cells, using any cell for a nonhomologous use (for example an adipose MSC for an orthopedic indication), and cells that have significant processing beyond a simple centrifugation. This regulatory posture has led to a prolonged approval process to bring these technologies from the bench to the bedside. While this approach may certainly make sense for mass produced cells being distributed en masse in vials, this same approach is also applied to autologous cells where the lot size is one patient. As a result, real world clinical knowledge on the clinical use of stem cells in patients is largely accumulating outside the U.S. and Europe. Many stem cell clinics have proliferated worldwide in countries with less stringent regulatory structures.

\section{References}

Agung, M., Ochi, M., Yanada, S., Adachi, N., Izuta, Y., Yamasaki, T. \& Toda, K. (2006). Mobilization of bone marrow-derived mesenchymal stem cells into the injured tissues after intraarticular injection and their contribution to tissue regeneration. Knee Surg Sports Traumatol Arthrosc, Vol. 14, No. 12, pp. 1307-1314, ISSN 0942-2056.

Alhadlaq, A. \& Mao, J.J. (2004). Mesenchymal stem cells: isolation and therapeutics. Stem Cells Dev, Vol. 13, No. 4, pp. 436-448.

Ando, W., Tateishi, K., Hart, D.A., Katakai, D., Tanaka, Y., Nakata, K., Hashimoto, J., Fujie, H., Shino, K., Yoshikawa, H. \& Nakamura, N. (2007). Cartilage repair using an in vitro generated scaffold-free tissue-engineered construct derived from porcine synovial mesenchymal stem cells. Biomaterials, Vol. 28, No. 36, pp. 5462-5470, ISSN 0142-9612.

Angele, P., Kujat, R., Nerlich, M., Yoo, J., Goldberg, V. \& Johnstone, B. (1999). Engineering of osteochondral tissue with bone marrow mesenchymal progenitor cells in a derivatized hyaluronan-gelatin composite sponge. Tissue Eng, Vol. 5, No. 6, pp. 545554, ISSN 1076-3279. 
Awad, H.A., Butler, D.L., Boivin, G.P., Smith, F.N., Malaviya, P., Huibregtse, B. \& Caplan, A.I. (1999). Autologous mesenchymal stem cell-mediated repair of tendon. Tissue Eng, Vol. 5, No. 3, pp. 267-277.

Awad, H.A., Butler, D.L., Harris, M.T., Ibrahim, R.E., Wu, Y., Young, R.G., Kadiyala, S. \& Boivin, G.P. (2000). In vitro characterization of mesenchymal stem cell-seeded collagen scaffolds for tendon repair: effects of initial seeding density on contraction kinetics. J Biomed Mater Res, Vol. 51, No. 2, pp. 233-240, ISSN 1097-4636.

Banfi, A., Muraglia, A., Dozin, B., Mastrogiacomo, M., Cancedda, R. \& Quarto, R. (2000). Proliferation kinetics and differentiation potential of ex vivo expanded human bone marrow stromal cells: Implications for their use in cell therapy. Exp Hematol, Vol. 28, No. 6, pp. 707-715, ISSN 0301-472X.

Barry, F.P. (2003). Mesenchymal stem cell therapy in joint disease. Novartis Found Symp, Vol. 249, No. 86-96; discussion 96-102, pp. 170-104, 239-141.

Becker, A.J., Mc, C.E. \& Till, J.E. (1963). Cytological demonstration of the clonal nature of spleen colonies derived from transplanted mouse marrow cells. Nature, Vol. 197, pp. 452-454, ISSN 0028-0836.

Brittberg, M., Lindahl, A., Nilsson, A., Ohlsson, C., Isaksson, O. \& Peterson, L. (1994). Treatment of deep cartilage defects in the knee with autologous chondrocyte transplantation. N Engl J Med, Vol. 331, No. 14, pp. 889-895, ISSN 0028-4793.

Broberg, K., Hoglund, M., Lindstrand, A., Toksvig-Larsen, S., Mandahl, N. \& Mertens, F. (1998). Polyclonal expansion of cells with trisomy 7 in synovia from patients with osteoarthritis. Cytogenet Cell Genet, Vol. 83, No. 1-2, pp. 30-34, ISSN 0301-0171.

Bruder, S.P., Fink, D.J. \& Caplan, A.I. (1994). Mesenchymal stem cells in bone development, bone repair, and skeletal regeneration therapy. J Cell Biochem, Vol. 56, No. 3, pp. 283-294.

Buckwalter, J.A. \& Mankin, H.J. (1998). Articular cartilage: degeneration and osteoarthritis, repair, regeneration, and transplantation. Instr Course Lect, Vol. 47, pp. 487-504.

Caplan, A.I. (1991). Mesenchymal stem cells. J Orthop Res, Vol. 9, No. 5, pp. 641-650, ISSN 1554-527X.

Centeno, C.J., Busse, D., Kisiday, J., Keohan, C., Freeman, M. \& Karli, D. (2008). Increased knee cartilage volume in degenerative joint disease using percutaneously implanted, autologous mesenchymal stem cells. Pain Physician, Vol. 11, No. 3, pp. 343-353, ISSN 1533-3159.

Centeno, C.J., Busse, D., Kisiday, J., Keohan, C., Freeman, M. \& Karli, D. (2008). Regeneration of meniscus cartilage in a knee treated with percutaneously implanted autologous mesenchymal stem cells. Med Hypotheses, Vol. 71, No. 6, pp. 900-908, ISSN 0306-9877.

Centeno, C.J., Kisiday, J., Freeman, M. \& Schultz, J.R. (2006). Partial regeneration of the human hip via autologous bone marrow nucleated cell transfer: A case study. Pain Physician, Vol. 9, No. 3, pp. 253-256, ISSN 1533-3159.

Centeno, C.J., Schultz, J.R., Cheever, M., Robinson, B., Freeman, M. \& Marasco, W. (2010). Safety and complications reporting on the re-implantation of culture-expanded mesenchymal stem cells using autologous platelet lysate technique. Curr Stem Cell Res Ther, Vol. No. 5, pp. 81-93, ISSN 1574-888X.

Cha, J. \& Falanga, V. (2007). Stem cells in cutaneous wound healing. Clin Dermatol, Vol. 25, No. 1, pp. 73-78, ISSN 0738-081X. 
Chong, A.K., Ang, A.D., Goh, J.C., Hui, J.H., Lim, A.Y., Lee, E.H. \& Lim, B.H. (2007). Bone marrow-derived mesenchymal stem cells influence early tendon-healing in a rabbit achilles tendon model. J Bone Joint Surg Am, Vol. 89, No. 1, pp. 74-81, ISSN 00219355.

Crisostomo, P.R., Wang, M., Wairiuko, G.M., Morrell, E.D., Terrell, A.M., Seshadri, P., Nam, U.H. \& Meldrum, D.R. (2006). High passage number of stem cells adversely affects stem cell activation and myocardial protection. Shock, Vol. 26, No. 6, pp. 575-580.

Deyo, R.A., Ciol, M.A., Cherkin, D.C., Loeser, J.D. \& Bigos, S.J. (1993). Lumbar spinal fusion. A cohort study of complications, reoperations, and resource use in the Medicare population. Spine, Vol. 18, No. 11, pp. 1463-1470, ISSN 0362-2436.

Elias, W.J., Simmons, N.E., Kaptain, G.J., Chadduck, J.B. \& Whitehill, R. (2000). Complications of posterior lumbar interbody fusion when using a titanium threaded cage device. J Neurosurg, Vol. 93, No. 1, pp. 45-52.

Fiedler, J., Roderer, G., Gunther, K.P. \& Brenner, R.E. (2002). BMP-2, BMP-4, and PDGF-bb stimulate chemotactic migration of primary human mesenchymal progenitor cells. $J$ Cell Biochem, Vol. 87, No. 3, pp. 305-312, ISSN 1097-4644.

Friedenstein, A.J., Deriglasova, U.F., Kulagina, N.N., Panasuk, A.F., Rudakowa, S.F., Luria, E.A. \& Ruadkow, I.A. (1974). Precursors for fibroblasts in different populations of hematopoietic cells as detected by the in vitro colony assay method. Exp Hematol, Vol. 2, No. 2, pp. 83-92, ISSN 0301-472X.

Frisbie, D.D., Kisiday, J.D., Kawcak, C.E., Werpy, N.M. \& Mcllwraith, C.W. (2009). Evaluation of adipose-derived stromal vascular fraction or bone marrow-derived mesenchymal stem cells for treatment of osteoarthritis. J Orthop Res, Vol. 27, No. 12., pp. 1675-1680, ISSN 1554-527X.

Fritzell, P., Hagg, O. \& Nordwall, A. (2003). Complications in lumbar fusion surgery for chronic low back pain: comparison of three surgical techniques used in a prospective randomized study. A report from the Swedish Lumbar Spine Study Group. Eur Spine J, Vol. 12, No. 2, pp. 178-189, ISSN 0940-6719.

Gangji, V., Toungouz, M. \& Hauzeur, J.P. (2005). Stem cell therapy for osteonecrosis of the femoral head. Expert Opin Biol Ther, Vol. 5, No. 4, pp. 437-442.

Gulotta, L.V., Kovacevic, D., Ehteshami, J.R., Dagher, E., Packer, J.D. \& Rodeo, S.A. (2009). Application of bone marrow-derived mesenchymal stem cells in a rotator cuff repair model. Am J Sports Med, Vol. 37, No. 11, pp. 2126-2133, ISSN 1552-3365.

Haleem, A.M., Singergy, A.A., Sabry, D., Atta, H.M., Rashed, L.A., Chu, C.R., El Shewy, M.T., Azzam, A. \& Abdel Aziz, M.T. (2010). The Clinical Use of Human CultureExpanded Autologous Bone Marrow Mesenchymal Stem Cells Transplanted on Platelet-Rich Fibrin Glue in the Treatment of Articular Cartilage Defects: A Pilot Study and Preliminary Results. Cartilage, Vol. 1, No. 4, pp. 253-261, ISSN 1947-6043.

HCUP. A. f. H. R. a. Quality. \& 2008). Nationwide Inpatient Sample Issue.

Hennerbichler, A., Moutos, F.T., Hennerbichler, D., Weinberg, J.B. \& Guilak, F. (2007). Repair response of the inner and outer regions of the porcine meniscus in vitro. Am J Sports Med, Vol. 35, No. 5, pp. 754- 762, ISSN 0363-5465.

Huang, X.P., Sun, Z., Miyagi, Y., McDonald Kinkaid, H., Zhang, L., Weisel, R.D. \& Li, R.K. (2010). Differentiation of allogeneic mesenchymal stem cells induces immunogenicity and limits their long-term benefits for myocardial repair. Circulation, Vol. 122, No. 23, pp. 2419-2429, ISSN 1524-4539. 
Izadpanah, R., Kaushal, D., Kriedt, C., Tsien, F., Patel, B., Dufour, J. \& Bunnell, B.A. (2008). Long-term in vitro expansion alters the biology of adult mesenchymal stem cells. Cancer Res, Vol. 68, No. 11, pp. 4229-4238, ISSN 1538-7445.

Izuta, Y., Ochi, M., Adachi, N., Deie, M., Yamasaki, T. \& Shinomiya, R. (2005). Meniscal repair using bone marrow-derived mesenchymal stem cells: experimental study using green fluorescent protein transgenic rats. Knee, Vol. 12, No. 3, pp. 217-223, ISSN 0968-0160.

Johnstone, B. \& Yoo, J.U. (1999). Autologous mesenchymal progenitor cells in articular cartilage repair. Clin Orthop Relat Res, Vol. 367, S156-162.

Katakai, D., Imura, M., Ando, W., Tateishi, K., Yoshikawa, H., Nakamura, N. \& Fujie, H. (2009). Compressive properties of cartilage-like tissues repaired in vivo with scaffold-free, tissue engineered constructs. Clin Biomech (Bristol, Avon), Vol. 24, No. 1, pp. 110-116, ISSN 1879-1271.

Kobayashi, T., Ochi, M., Yanada, S., Ishikawa, M., Adachi, N., Deie, M. \& Arihiro, K. (2008). A novel cell delivery system using magnetically labeled mesenchymal stem cells and an external magnetic device for clinical cartilage repair. Arthroscopy, Vol. 24, No. 1, pp. 69-76, ISSN 1526-3231.

Koga, H., Shimaya, M., Muneta, T., Nimura, A., Morito, T., Hayashi, M., Suzuki, S., Ju, Y.J., Mochizuki, T. \& Sekiya, I. (2008). Local adherent technique for transplanting mesenchymal stem cells as a potential treatment of cartilage defect. Arthritis Res Ther, Vol. 10, No. 4, pp. R84.

Ladage, D., Brixius, K., Steingen, C., Mehlhorn, U., Schwinger, R.H., Bloch, W. \& Schmidt, A. (2007). Mesenchymal stem cells induce endothelial activation via paracine mechanisms. Endothelium, Vol. 14, No. 2, pp. 53-63.

Mahomed NN, B.J., Katz JN, Baron JA, Wright J, Losina E (2005). Epidemiology of total knee replacement in the United States Medicare population. J Bone Joint Surg Am, Vol. 87, No. 6, ISSN 1222-1228.

McIlwraith, C.W., Frisbie, D.D., Kisiday, J.D., Kawcak, C.E., Werpy, N.M., Rodkey, W.G., \& Steadman, R.S. (2010) Use of bone marrow-derived culture-expanded mesenchymal stem cells to augment healing of chondral defects treated with microfracture In: Proceedings of the 56 th Annual Convention of the American Association of Equine Practitioners, Moyer, W.A. pp. 27-28. Baltimore, Marlyand, USA.

Minas, T. \& Nehrer, S. (1997). Current concepts in the treatment of articular cartilage defects. Orthopedics, Vol. 20, No. 6, pp. 525-538, ISSN 0147-7447.

Mobasheri, A., Csaki, C., Clutterbuck, A.L., Rahmanzadeh, M. \& Shakibaei, M. (2009). Mesenchymal stem cells in connective tissue engineering and regenerative medicine: applications in cartilage repair and osteoarthritis therapy. Histol Histopathol, Vol. 24, No. 3, pp. 347-366, ISSN 1699-5848.

Nejadnik, H., Hui, J.H., Choong, E.P., Tai, B.C. \& Lee, E.H. (2010). Autologous Bone Marrow-Derived Mesenchymal Stem Cells Versus Autologous Chondrocyte Implantation: An Observational Cohort Study. Am J Sports Med, Vol. 38, No. 6, pp. 1110-1116, ISSN 1552-3365.

Niemeyer, P., Fechner, K., Milz, S., Richter, W., Suedkamp, N.P., Mehlhorn, A.T., Pearce, S. \& Kasten, P. (2010). Comparison of mesenchymal stem cells from bone marrow and adipose tissue for bone regeneration in a critical size defect of the sheep tibia and 
the influence of platelet-rich plasma. Biomaterials, Vol. 31, No. 13, pp. 3572-3579, ISSN 1878-5905.

Prigozhina, T.B., Khitrin, S., Elkin, G., Eizik, O., Morecki, S. \& Slavin, S. (2008). Mesenchymal stromal cells lose their immunosuppressive potential after allotransplantation. Exp Hematol, Vol 36, No. 10, pp. 1370-1376, ISSN 0301$472 X$.

Sakai, D., Mochida, J., Yamamoto, Y., Nomura, T., Okuma, M., Nishimura, K., Nakai, T., Ando, K. \& Hotta, T. (2003). Transplantation of mesenchymal stem cells embedded in Atelocollagen gel to the intervertebral disc: a potential therapeutic model for disc degeneration. Biomaterials, Vol. 24, No. 20, pp. 3531-3541, ISSN 0142-9612.

Schauwer, C.D., Meyer, E., Walle, G.R. \& Soom, A.V. (2010). Markers of stemness in equine mesenchymal stem cells: a plea for uniformity. Theriogenology, Vol. 75, No. 8, pp. 1431-1443, ISSN 0093-691X.

Sturnieks, D.L., Besier, T.F. \& Lloyd, D.G. (2010). Muscle activations to stabilize the knee following arthroscopic partial meniscectomy. Clin Biomech (Bristol, Avon), Vol. 26, No. 3. pp. 292-297, ISSN 1879-1271.

Ueda, Y., Inaba, M., Takada, K., Fukui, J., Sakaguchi, Y., Tsuda, M., Omae, M., Kushida, T., Iida, H. \& Ikehara, S. (2007). Induction of senile osteoporosis in normal mice by intra-bone marrow-bone marrow transplantation from osteoporosis-prone mice. Stem Cells, Vol. 25, No. 6, pp. 1356-1363, ISSN 1549-4918.

Vidal, M.A., Robinson, S.O., Lopez, M.J., Paulsen, D.B., Borkhsenious, O., Johnson, J.R., Moore, R.M. \& Gimble, J.M. (2008). Comparison of chondrogenic potential in equine mesenchymal stromal cells derived from adipose tissue and bone marrow. Vet Surg, Vol. 37, No. 8, pp. 713-724, ISSN 1532-950X.

Wakitani, S., Nawata, M., Tensho, K., Okabe, T., Machida, H. \& Ohgushi, H. (2007). Repair of articular cartilage defects in the patello-femoral joint with autologous bone marrow mesenchymal cell transplantation: three case reports involving nine defects in five knees. J Tissue Eng Regen Med, Vol. 1, No. 1, pp. 74-79, ISSN 19327005 .

Wakitani, S., Okabe, T., Horibe, S., Mitsuoka, T., Saito, M., Koyama, T., Nawata, M., Tensho, K., Kato, H., Uematsu, K., Kuroda, R., Kurosaka, M., Yoshiya, S., Hattori, K. \& Ohgushi, H. (2010). Safety of autologous bone marrow-derived mesenchymal stem cell transplantation for cartilage repair in 41 patients with 45 joints followed for up to 11 years and 5 months. J Tissue Eng Regen Med, Vol. 5, No. 2, pp. 146-150, ISSN 1932-7005.

Yoshikawa, T., Ueda, Y., Miyazaki, K., Koizumi, M. \& Takakura, Y. (2010). Disc regeneration therapy using marrow mesenchymal cell transplantation: a report of two case studies. Spine (Phila Pa 1976), Vol. 35, No. 11, pp. E475-480, ISSN 1528-1159.

Yoshimura, H., Muneta, T., Nimura, A., Yokoyama, A., Koga, H. \& Sekiya, I. (2007). Comparison of rat mesenchymal stem cells derived from bone marrow, synovium, periosteum, adipose tissue, and muscle. Cell Tissue Res, Vol. 327, No. 3, pp. 449-462, ISSN 0302-766X.

Zhou, S., Greenberger, J.S., Epperly, M.W., Goff, J.P., Adler, C., Leboff, M.S. \& Glowacki, J. (2008). Age-related intrinsic changes in human bone-marrow-derived mesenchymal 
stem cells and their differentiation to osteoblasts. Aging Cell, Vol. 7, No. 3, pp. 335343, ISSN 1474-9726.

Zhou, Z., Jiang, E.L., Wang, M., Liu, Q.G., Zhai, W.J., Huang, Y., Wang, H.H. \& Han, M.Z. (2005). [Comparative study on various subpopulations in mesenchymal stem cells of adult bone marrow]. Zhongguo Shi Yan Xue Ye Xue Za Zhi, Vol. 13, No. 1, pp. 5458, ISSN 1009-2137. 


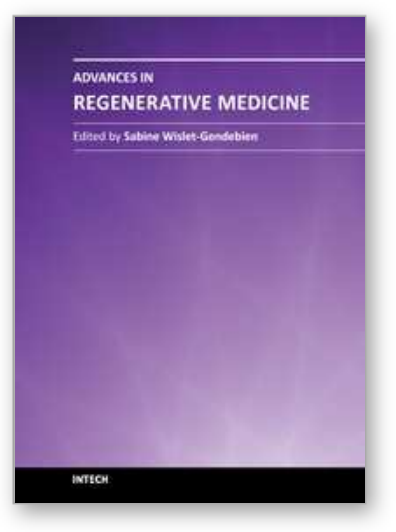

\author{
Advances in Regenerative Medicine \\ Edited by Dr Sabine Wislet-Gendebien
}

ISBN 978-953-307-732-1

Hard cover, 404 pages

Publisher InTech

Published online 21, November, 2011

Published in print edition November, 2011

Even if the origins of regenerative medicine can be found in Greek mythology, as attested by the story of Prometheus, the Greek god whose immortal liver was feasted on day after day by Zeus' eagle; many challenges persist in order to successfully regenerate lost cells, tissues or organs and rebuild all connections and functions. In this book, we will cover a few aspects of regenerative medicine highlighting major advances and remaining challenges in cellular therapy and tissue/organ engineering.

\title{
How to reference
}

In order to correctly reference this scholarly work, feel free to copy and paste the following:

Christopher J. Centeno and Stephen J. Faulkner (2011). Regenerative Orthopedics, Advances in Regenerative Medicine, Dr Sabine Wislet-Gendebien (Ed.), ISBN: 978-953-307-732-1, InTech, Available from: http://www.intechopen.com/books/advances-in-regenerative-medicine/regenerative-orthopedics

\section{INTECH}

open science | open minds

\author{
InTech Europe \\ University Campus STeP Ri \\ Slavka Krautzeka 83/A \\ 51000 Rijeka, Croatia \\ Phone: +385 (51) 770447 \\ Fax: +385 (51) 686166 \\ www.intechopen.com
}

\author{
InTech China \\ Unit 405, Office Block, Hotel Equatorial Shanghai \\ No.65, Yan An Road (West), Shanghai, 200040, China \\ 中国上海市延安西路65号上海国际贵都大饭店办公楼 405 单元 \\ Phone: +86-21-62489820 \\ Fax: +86-21-62489821
}


(C) 2011 The Author(s). Licensee IntechOpen. This is an open access article distributed under the terms of the Creative Commons Attribution 3.0 License, which permits unrestricted use, distribution, and reproduction in any medium, provided the original work is properly cited. 